\title{
Chilling injury alleviation and quality maintenance of lemon basil by preharvest salicylic acid treatment
}

\author{
Suriyan Supapvanich*, Rachadakorn Phonpakdee, Pratumtip Wongsuwan \\ Department of Agricultural Education, Faculty of Industrial Education, King Mongkut's Institute of Technology Ladkrabang, Chalongkrung road, \\ Ladkrabang, Bangkok 10520, Thailand
}

\section{A B S T R A C T}

\begin{abstract}
The purpose of this study was to alleviate chilling injury (CI) of lemon basil during storage by using preharvest salicylic acid (SA) treatment. The basil was sprayed with SA at the concentration of $0,1,5$ or $10 \mathrm{mM}$ before harvesting $24 \mathrm{~h}$ and was then stored at $7{ }^{\circ} \mathrm{C}$ for 4 days. Weight loss, $\mathrm{Cl}$ score, malondialdehyde (MDA) content, electrolyte leakage (EL), superficial colour, pigments and bioactive compounds were determined. SA treatments alleviated $\mathrm{Cl}$ and reduced the increase in $\mathrm{EL}$ and $\mathrm{MDA}$ content which the best result alleviating $\mathrm{Cl}$ was $5 \mathrm{mM}$ SA. The greenness and total chlorophyll content were maintained by SA application. After $24 \mathrm{~h}$ of treatment, antioxidants, total phenols and flavonoids were enhanced. During storage, SA treatment reduced the loss of bioactive compounds in the lemon basil. In conclusion, preharvest $\mathrm{SA}$ treatment at $5 \mathrm{mM}$ alleviated $\mathrm{Cl}$ and maintained quality of lemon basil during cold storage.
\end{abstract}

Keywords: Lemon basil; Salicylic acid; Preharvest treatment; Chilling injury; Bioactive compounds

\section{INTRODUCTION}

Basils (Ocimum sp.), one of most popular culinary herb, are widely used as a flavoring agent in Asian cuisine, especially Thai food. In Thailand, there are three commercial basils; lemon basil (Ocimum $x$ citriodourum), sweet basil (Ocimumbasilicum) and holy basil (Ocimum sanctum) which are widely consumed in country and exported to European and other Western countries in form of cut herb. Recently, these basils have commercially grown in European countries during summer period and the consumption demand has also increased as its favorable aroma and medicinal properties. As having medicinal properties, basils are a rich sources of biologically active compounds involving phenolic compounds, flavonoids and antioxidants (Hakkim et al., 2007). Commercially, fresh fruit and vegetables are held at cold temperature during transportation, but low temperature in a mixed-load shipment cause problems for chilling-sensitive produces, especially tropical leafy herbs (Lange and Cameron, 1997). Among the three commercial basils, lemon basil is relatively high sensitive to storage at low temperature which resulted in leaf blackening which limiting its quality and shelf-life (Wongsheree et al., 2009). The chilling injury (CI) of basil is associated with the dysfunction of oil gland in leaf which the browning spots were observed and then expanded through CI development (Pongprasert and Srilaong, 2007). At $4^{\circ} \mathrm{C}$, the visible blackening spots in mature lemon basil leaves is found in $12 \mathrm{~h}$ and then rapidly increase hereafter whilst at $12^{\circ} \mathrm{C}$ the blackening spots appeared in 5 days (Wongsheree et al., 2009). In other basils, the onset of blackening spots of sweet basil held at $4-5^{\circ} \mathrm{C}$ is 1 day (Lange and Cameron, 1997; Pongprasert and Srilaong, 2007) and that of holy basil held the $5^{\circ} \mathrm{C}$ noticeably appears in 3 days of storage (Niamthong et al., 2007).

It is widely recognized that CI is accompanied by dysfunction of cell membrane due to lipid peroxidation and oxidative stress. In CI temperatures, elevated levels of reactive oxygen species (ROS), particularly $\mathrm{H}_{2} \mathrm{O}_{2}$, have been detected (Elwan and El-Hamahmy, 2009). Generally, there is a balance between the generation of ROS and ROS scavenging system in plant. The ROS can be minimized and removed by antioxidant defense mechanisms (Gülçin et al., 2007). Recently, salicylic acid, a plant growth regulator and a safe chemical used to maintain postharvest quality, has been proven to be a major component inducing bioactive compounds such as antioxidants and

\footnotetext{
*Corresponding author:

Suriyan Supapvanich, Department of Agricultural Education, Faculty of Industrial Education, King Mongkut's Institute of Technology

Ladkrabang, Chalongkrung road, Ladkrabang, Bangkok-10520, Thailand. E-mail: kusuriya@kmitl.ac.th

Received: 02 August 2015; Revised: 17 September 2015; Accepted: 18 September 2015; Published Online: 18 September 2015
} 
antioxidant enzymes (Supapvanich and Promyou, 2013). Elwan and El-Hamahmy (2009) suggested that a range of antioxidant enzyme activities such as catalase (CAT), guaiacol peroxidase (G-POD) and asborbate peroxidase (A-POD) play important roles in removing $\mathrm{H}_{2} \mathrm{O}_{2}$ which these enzyme activities are induced by SA. Hatamzadeh et al. (2012) suggested that SA is able to eliminate ROS and lead to decreasing lipid peroxidation. Not only does bioactive compounds induced by SA stimulating tolerance stress system in plant but these compounds also provide health benefit to human beings. However, no information has been reported on the preharvest SA application on postharvest quality and bioactive compounds of lemon basil. Thus the purpose of this study was to investigate the effect of preharvest SA application on quality maintenance and bioactive compound levels of lemon basil during cold storage.

\section{MATERIALS AND METHODS}

\section{Plant materials preparation and treatments}

Lemon basil (Ocimum $\times$ citriodourum) was cultivated at agricultural demonstration plot, Faculty of Agricultural Engineering, King Mongkut's Institute of Technology Ladkrabang, in May 2014. After 2 months of cultivation, they were sprayed with SA solution at the concentration of $0,1,5$ or $10 \mathrm{mM}$. The lemon basils were harvested after SA spraying $24 \mathrm{~h}$ in morning (6:30-7:30 am) by using sharp clipper. The vegetables were then delivered to the laboratory at Department of Agricultural Education within $15 \mathrm{~min}$ after harvested. The vegetables were screened being free of any physical damages or disease. The vegetable shoots were cut in $15 \mathrm{~cm}$ length. The vegetables were cleaned by rinsing with tapped water and then immersed in $50 \mu \mathrm{L} \mathrm{L}^{-1}$ sodium hypochloride solution for $2 \mathrm{~min}$. The excess surface water was removed by using a shaking basket. Twenty grams of the vegetables were contained in a laminated polyethylene plastic bag, size $22.9 \times 10.2 \mathrm{~cm}$ and then the bag was sealed. The vegetable was stored at $7 \pm 1{ }^{\circ} \mathrm{C}$ and $85 \pm 2 \% \mathrm{RH}$ for 4 days.

\section{Weight loss and superficial colour measurement}

The loss of fresh weight was monitored before and during storage. The lemon basils were weighed on initial day and during storage at 2 and 4 days. The percentage of fresh weight loss during storage was calculated compared to the initial weight. Superficial colour of the lemon basil (10 leaves) was measured using a colorimeter (Minolta CR300, Minolta Co. Ltd. Japan). Colour measurements, brightness $\left(L^{*}\right)$, greenness $\left(-a^{*}\right)$, chroma and hue values, were taken.

\section{Chilling injury score measurement}

Chilling injury (CI) of lemon basil during storage was estimated using the score of CI symptoms (browning fleck) on the leaves. The CI severity was rated on a relative scale of 1 to 5 where: $1=$ no CI symptom, $3=$ moderate and $5=$ severe (Supapvanich et al., 2012).

\section{Electrolyte leakage measurement}

The electrolyte leakage of lemon basil leaves was carried out using method describe by Promyou et al. (2012) with slight modification. Ten leaves of the lemon basil were half cut using a sharp blade. The weight of cut lemon basil leaves was recorded. The cut leaves were rinsed with de-ionized water twice and dried using a Whatman No. 1 filter paper. The cut leaves were incubated in $30 \mathrm{~mL}$ of de-ionized water at ambient temperature $\left(28 \pm 1{ }^{\circ} \mathrm{C}\right)$ and shaken for $60 \mathrm{~min}$. The conductivity of the solution was immediately measured at $0 \mathrm{~min}$ and again at $60 \mathrm{~min}$ using a conductivity tester (DiST3, Hunna Instruments Inc., Romania). The sample was then frozen for $24 \mathrm{~h}$ and thawed. After that, the sample was boiled for $10 \mathrm{~min}$. The conductivity (total conductivity) was again measured after the solution temperature drop to ambient temperature. The percentage of conductivity increase per $1 \mathrm{~h}$ was calculated which compared to the total conductivity.

\section{Malondialdehyde (MDA) content assay}

A sample of $5 \mathrm{~g}$ of lemon basil leaves was homogenized in $20 \mathrm{~mL}$ of $5 \%$ trichloroacetic acid (TCA) and then centrifuged at $10,000 \times \mathrm{g}$ for $20 \mathrm{~min}$. The supernatant was used to assay MDA content using method described by Heath and Packer (1968) with slight modification. The reaction began when $1 \mathrm{~mL}$ of supernatant was mixed with $2 \mathrm{~mL}$ of $15 \%$ TCA containing $0.5 \%$ thiobarbituric acid (TBA). The mixture was heated at $60{ }^{\circ} \mathrm{C}$ for $30 \mathrm{~min}$ and immediately cooled using an ice bath for $30 \mathrm{~min}$. The absorbance of the mixture was then measured at 532 and $600 \mathrm{~nm}$, respectively. The MDA content was calculated using an extinction coefficient of $1.55 \mathrm{mM} \mathrm{cm}^{-1}$ as follows: MDA content $=\left[\left(\mathrm{OD}_{532}-\mathrm{OD}_{600}\right) \times 2 \mathrm{~mL} \times(\right.$ total volume of extract $(\mathrm{mL}) \times 1 \mathrm{~mL})] /\left(1.55 \times 10^{-1} \times 5 \mathrm{~g}\right)$. The data were represented as nanomoles of MDA per gram fresh weight $\left(\mathrm{nmolg}{ }^{-1} \mathrm{FW}\right)$.

\section{Chlorophylls and carotenoid contents measurements} Chlorophylls and carotenoid contents were assayed according to the method of Kirk (1968) with slight modification. Three gram of lemon basil was homogenized with $10 \mathrm{~mL}$ of absolute ethanol. The sample was filtered using Whatman No. 1 filter paper and rinsed with $10 \mathrm{~mL}$ of absolute ethanol. The filtrate was collected and then adjusted to $50 \mathrm{~mL}$ using absolute ethanol. The absorbances at 654, 663 and $470 \mathrm{~nm}$ were measured using a Hekios UV-visible spectrophotometer (Thermo Spectronic, Cambridge, UK). Chlorophyll $a$ content was calculated as $\left(11.75 \times \mathrm{OD}_{645}\right)-\left(2.35 \times \mathrm{OD}_{663}\right)$, chlorophyll $b$ content was calculated as $\left(18.61 \times \mathrm{OD}_{645}\right)-\left(3.96 \times \mathrm{OD}_{663}\right)$.

Emir. J. Food Agric • Vol 27 • Issue 11 • 2015 
The sum of chlorophyll $a$ and chlorophyll $b$ was expressed as total chlorophylls content. The data was represented as $\mu \mathrm{g}$ total chlorophylls content per $100 \mathrm{~g}$ fresh weight. Total carotene was calculated as $\left[\left(1000 \times \mathrm{OD}_{470}\right)-\right.$ $(2.27 \times$ Chlorophyll $a)-(81.4 \times$ chlorophyll $b)] / 227$. The data was represented as $\mu \mathrm{g}$ carotene per $100 \mathrm{~g}$ fresh weight.

\section{FRAP value, $\mathrm{H}_{2} \mathrm{O}_{2}$ scavenging activity assays}

Antioxidant capacity was determined using ferric reducing antioxidant potential (FRAP) methods, which described by Benzie and Strain (1996). Three grams of the lemon basil leaves was homogenized with $5 \mathrm{~mL}$ of $80 \%$ (v/v) methanol and then $25 \mathrm{~mL}$ of distilled water was added. The suspension was stirred at $4{ }^{\circ} \mathrm{C}$ for $30 \mathrm{~min}$ and then filtered using Whatman No.1 filter paper. The filtrate was collected to determine FRAP value, $\mathrm{H}_{2} \mathrm{O}_{2}$ scavenging activity, total phenols (TP) and total flavonoids (TF) content. For FRAP assay, $0.1 \mathrm{~mL}$ of the extract was added into $2.9 \mathrm{~mL}$ FRAP reagent, consisting of acetate buffer $\mathrm{pH}$ 3, $10 \mathrm{mM}$ 2,4,6-tripyridyl-1,3,5-triazine (TPTZ) and $20 \mathrm{mM}$ ferric chloride hexahydrate in the ratio of 10:1:1. The reaction was held at ambient temperature for $30 \mathrm{~min}$ before measuring absorbance at $630 \mathrm{~nm}$. FRAP value was expressed as $\mu$ mole Trolox equivalents per $\mathrm{g}$ fresh weight. $\mathrm{H}_{2} \mathrm{O}_{2}$ scavenging activity was determined using titration method described by Zhang (2000). One $\mathrm{mL}$ of the extract was mixed with $0.1 \mathrm{~mL}$ of $0.1 \mathrm{mM} \mathrm{H}_{2} \mathrm{O}_{2}$, followed by 2 drops of $3 \%$ ammonium molybdate, $10 \mathrm{~mL}$ of $2 \mathrm{M}$ $\mathrm{H}_{2} \mathrm{SO}_{4}$ and $7.0 \mathrm{~mL}$ of $1.8 \mathrm{M} \mathrm{KI}$. The mixture solution was titrated with $5 \mathrm{mM} \mathrm{NaS}_{2} \mathrm{O}_{3}$ until colourless. The percentage of $\mathrm{H}_{2} \mathrm{O}_{2}$ scavenging was calculated as $\left[\left(\mathrm{V}_{0}-\mathrm{V}_{1}\right) / \mathrm{V}_{0}\right] \times 100$; $\mathrm{V} 0=$ volume of $5 \mathrm{mM} \mathrm{NaS}_{2} \mathrm{O}_{3}$ used to titrate the control in present of $\mathrm{H}_{2} \mathrm{O}_{2}$ (without extract) and $\mathrm{V}_{1}=$ the volume of $5 \mathrm{mM} \mathrm{NaS}_{2} \mathrm{O}_{3}$ used to titrate in the present of extract.

\section{Total phenolic and total flavonoids content assays}

TP content was determined using the method described by Slinkard and Singleton (1977). The reaction of TP content was started when $0.1 \mathrm{~mL}$ of the extract was added into the solution of $1.9 \mathrm{~mL} \mathrm{50 \%} \mathrm{(v/v)} \mathrm{Folin-Ciocalteu}$ reagent solution and $2 \mathrm{~mL}$ saturated $\mathrm{Na}_{2} \mathrm{CO}_{3}$ solution. The mixture was left at ambient temperature for $30 \mathrm{~min}$. The absorbance at $750 \mathrm{~nm}$ was recorded. TP content was expressed in term of $\mathrm{mg}$ gallic acid per $\mathrm{g}$ fresh weight. TF content was determined using method described by Jia et al. (1999). The reaction was started when $0.5 \mathrm{~mL}$ of the extract was mixed with $1.5 \mathrm{~mL}$ of distilled water, $75 \mu \mathrm{L}$ of $0.5 \% \mathrm{NaNO}_{2}$. The mixture was left for $6 \mathrm{~min}$ and then $150 \mu \mathrm{L}$ of $10 \% \mathrm{AlCl}_{3}-6 \mathrm{H}_{2} \mathrm{O}$ was added and allowed to stand for $5 \mathrm{~min}$. After that, $0.5 \mathrm{~mL}$ of $1 \mathrm{M} \mathrm{NaOH}$ was added. The absorbance at $510 \mathrm{~nm}$ was recorded. The data were expressed in term of $\mathrm{mg}$ catechin equivalents per $\mathrm{g}$ fresh weight.
Catalase, guaiacol peroxidase and ascorbate peroxidase activities assays

Three grams of lemon basil was homogenized with $20 \mathrm{~mL}$ of $0.1 \mathrm{M}$ phosphate buffer $(\mathrm{pH}$ 7) containing $0.2 \mathrm{~g}$ of polyvinylpolypyrrolidone (PVPP). The homogenate was filtered using Whatman No.1 filter paper. The filtrate was held in an ice bath. The assay of catalase (CAT) (EC 1.11.1.6) was determined using titrimetric method of Kar and Mishra (1976) and guaiacol peroxidases (G-POD) (EC 1.11.1.7) and ascorbate peroxidase (A-POD) (EC 1.11.1.11) activities were determined using method of Andrade Cuvi et al.(2011). Five $\mathrm{mL}$ of the mixture for CAT assay consisted of $3 \mathrm{~mL}$ of phosphate buffer ( $\mathrm{pH} 7.0), 1 \mathrm{~mL}$ of $0.01 \mathrm{mM}$ $\mathrm{H}_{2} \mathrm{O}_{2}$ and $1 \mathrm{~mL}$ of enzyme extract. After incubation for $1 \mathrm{~min}$ at ambient temperature $\left(27 \pm 1^{\circ} \mathrm{C}\right)$, the reaction was stopped by adding $10 \mathrm{~mL}$ of $2 \% \mathrm{H}_{2} \mathrm{SO}_{4}$, The residual $\mathrm{H}_{2} \mathrm{O}_{2}$ was titrated against $0.01 \mathrm{M} \mathrm{KMnO}_{4}$ until a faint purple colour persisted for at least $20 \mathrm{sec}$. A control was the same mixture but the enzyme activity was stopped at $0 \mathrm{~min}$. Unit of CAT is defined as that amount of enzyme which break down $1 \mu \mathrm{mol}$ of $\mathrm{H}_{2} \mathrm{O}_{2} / \mathrm{min}$. The reaction mixture of G-POD contained $0.6 \mathrm{~mL}$ of $0.5 \%(\mathrm{v} / \mathrm{v})$ guaiacol, $0.5 \mathrm{~mL}$ of enzyme extract and $1.6 \mathrm{~mL}$ of phosphate buffer (pH 7.0). The reaction started when $0.3 \mathrm{~mL}$ of $40 \mathrm{mM}$ $\mathrm{H}_{2} \mathrm{O}_{2}$ was added. The G-POD activity was determined by monitoring the increase in the absorbance at $470 \mathrm{~nm}$. The unit of the enzyme activity was expressed as the $\triangle O D$ per min (unit) per $g$ fresh weight. The mixture of A-POD consisted of $0.5 \mathrm{~mL}$ of $5 \mathrm{mM}$ ascorbic acid, $0.5 \mathrm{~mL}$ of enzyme extract and $1.5 \mathrm{~mL}$ of phosphate buffer $(\mathrm{pH} 7.0)$ and the reaction began when $0.5 \mathrm{~mL}$ of $\mathrm{H}_{2} \mathrm{O}_{2}$ was added. The absorbance at $290 \mathrm{~nm}$ was expressed as the amount of enzyme that oxidized 0.01 mmole ascorbate per minute (unit) per $g$ fresh weight. The activity of CAT, G-POD and A-POD were expressed as unitg ${ }^{-1} \mathrm{FW}$.

\section{Statistical analysis}

The data are shown as the mean of four replications and S.D. bar. Data were analyzed using analysis of variance (ANOVA) which was performed with the SPSS software. The means of data were compared by the least significant difference (LSD) test at a significance level of 0.05 .

\section{RESULTS AND DISCUSSION}

\section{Weight loss and chilling injury}

As the result shown in Fig. 1A, preharvest SA treatments had no effect on the loss of fresh weight during cold storage. The weight loss of lemon basil were approximately $3.18 \%$ and $4.22 \%$ on day 2 and 4 , respectively (Fig. 1A). The main factor affecting the loss of fresh weight of the lemon basil during storage could be relative humidity as describe by Supapvanich et al. (2012). The CI symptom of 
lemon basil was generally characterized by leaf blackening and brown spot on leaveswhich due to the dynsfunction of oil glands (Wongsheree et al., 2009; Pongorsert and Srilaong, 2007).As expected, the CI score of lemon basil increased during stored at $7^{\circ} \mathrm{C}$. The onset of CI symptom appeared on day 2 and $\mathrm{SA}$ treatments were able to alleviate CI of the basil leaves (Fig. 1B). We found that $5 \mathrm{mM} \mathrm{SA}$ application was the most effective in alleviating $\mathrm{CI}$ in the basil when compared to other concentrations. At the end of storage (day 4), the CI score of $5 \mathrm{mM} \mathrm{SA}$-treated lemon basil was significantly lower than that of others $(P \leq$ 0.05 ) which it was lower than 2.5 (acceptable score) whilst the CI score of the control was about 4 (Fig. 1B). This may due to the induction of defense mechanism system by SA (Supapvanich and Promyou, 2013) which the cell membranestructure of oil glands in the basil leaves was also maintained. However, the use of SA at high concentration $(10 \mathrm{mM})$ caused tip-burn symptom on the shoot and young leaves (data not shown). In the similar vein, Babalar et al. (2007) and Elwan and El-Hamahmy (2009) had explained that the use of SA at a high concentration may harm the produce. This work shows that preharvest SA application at $5 \mathrm{mM}$ was a proper concentration controlling CI of lemon basil during cold storage. Therefore, the basil treated with 5 $\mathrm{mMSA}$ was selected to investigate physicochemical factors relating to chilling injury.

\section{Electrolyte leakage and MDA content}

Increase in EL and MDA content are commonly accepted as indicators of CI development during refrigerated storage of fresh commodities which due to the cell membrane dysfunction (McCollum and McDonald, 1991; Luo et al., 2011). As shown in Fig 2, the EL of the basil leaves increased throughout storage and that of the control was sinificantly higher than that of the SA-treated basil $(P \leq 0.05)$. This showed that preharvest SA application at $5 \mathrm{mM}$ was effective in preventing the membrane dysfunction due to CI alleviation. Similarly, Lukaszewska and Kobylińksi (2009) reported that SA application increased longevity of Hipperstrum x chmielii leaves by protecting membrane integrity and reducing the increase in electroconductivity of cell sap. The MDA content of both SA-treated and untreated lemon basil also increased following storage period (Fig. 2B). The increase in MDA content was related to lipid peroxidation of cell membrane which was concomitant with the increase in EL and CI during storage (McCollum and McDonald, 1991). The SA application reduced the increase in MDA content of lemon basil during storage. These show that preharvest SA application was able to alleviate CI incidence in lemon basil by maintaining cell membrane integrity and also reducing lipid peroxidation during cold exposure. In the similar vein, SA treatments delayed lipid

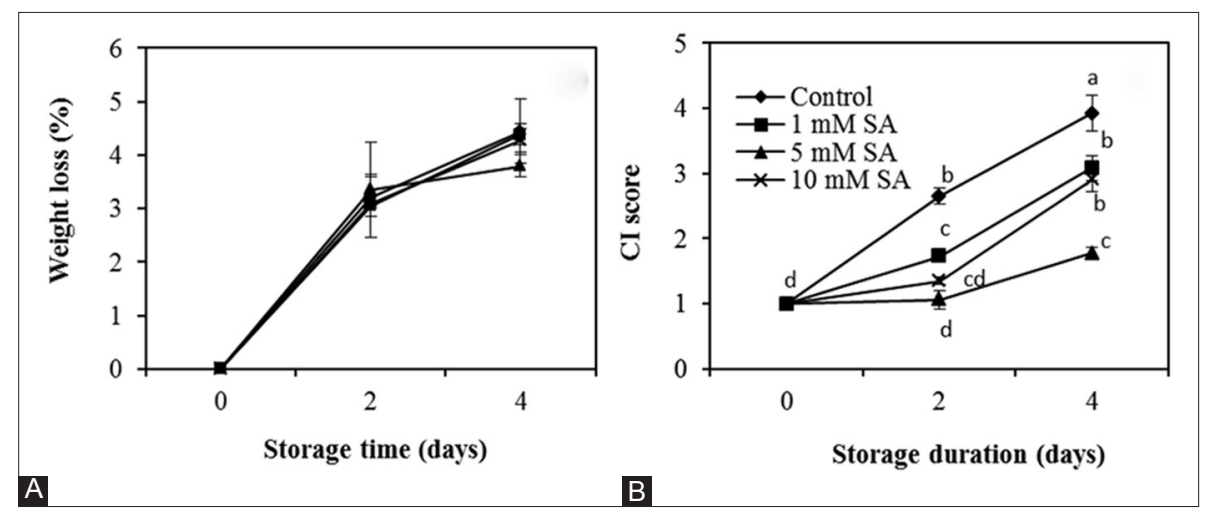

Fig 1. Wight loss $(\%)(A)$ and chilling injury $(\mathrm{Cl})$ score of SA preharvest-treated lemon basil at various SA concentration during storage at $7 \pm 1 \stackrel{\circ}{ } \mathrm{C}$ for 4 days. Data represent the mean of four replications \pm S.D.

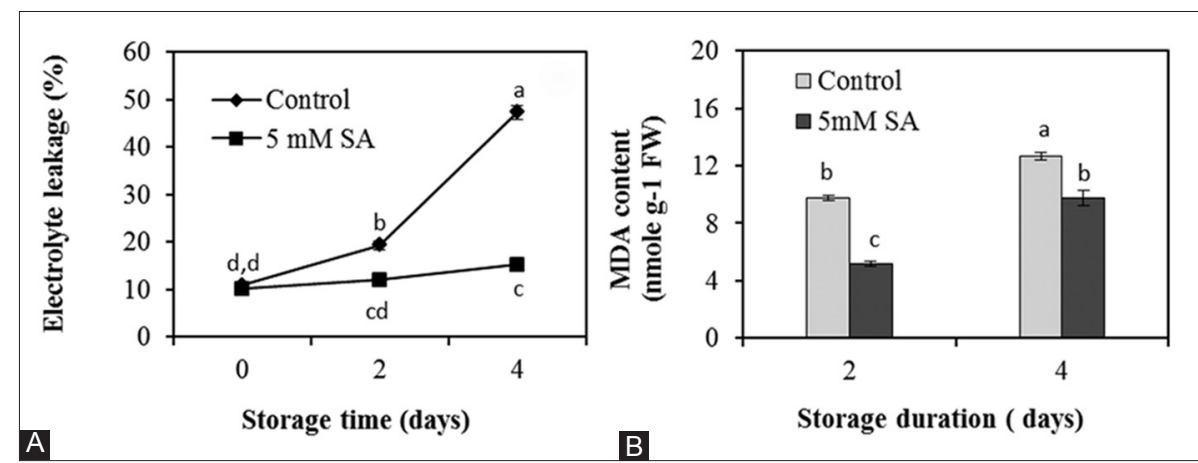

Fig 2. Electrolyte leakage (\%) (A) and malonaldehyde (MDA) content of lemon basil preharvest-treated with 0 and $5 \mathrm{mM}$ SA during storage at $7 \pm 1^{\circ} \mathrm{C}$ for 4 days. Data represent the mean of four replications \pm S.D. 
peroxidation and membrane dysfunction in pomegrante fruit (Awad et al., 2013) and plum fruit (Luo et al., 2011) during cold storage.

\section{Superficial colour and pigments}

Superficial colour is generally accepted as a main factor affecting the quality of leafy vegetables, especially greenness. As the results shown in Fig. 3, the SA treatment maintained the greeness and chroma value of lemon basil during cold storage whereas those of the control significantly decreased $(P<0.05)$. No significant difference in brightness and hue value of both SA-treated and untreated lemon basil leaves were found over storage. Similarly, Wei et al. (2011) reported that SA treatment could maintianed superficial colour of asparagus spears, due to delaying the deterioration in green colour. The changes in chlorophylls and total caroteniods content are generally related to the superficial colour. The loss of total chlorophyll content is concommitant with the loss of greeness and the occurance of yellowness of leafy vegetables (Supapvanich et al.,2012). In this study, the SA application maintained total chlorophyll content during storage whilst that of the untreated lemon basil was significantly decreased during storage $(P<0.05)$ (Fig. 4). Similarly, chlorophyll content and greenness of asparagus was maintained by SA use (Wei et al., 2011). The reduced chlorphyll content in the control was concomitant with the increase in total cartenoids content as shown in Fig. 4B. The total carotenoids content of SA-treated basil was maintained. These suggest that preharvest SA treatment was able to maintain superficial colour of lemon basil by retarding chlorophyll loss. These might involve with the increase in photosynthesis rate and the number of chloroplasts by SA which described by Radwan et al. (2008). Moreover, Li et al. (1992) and Kazemi et al. (2011) described that the inhibition of chlorophyll loss by SA application might due to the suppression of ACC synthase and ACC oxidase activities.

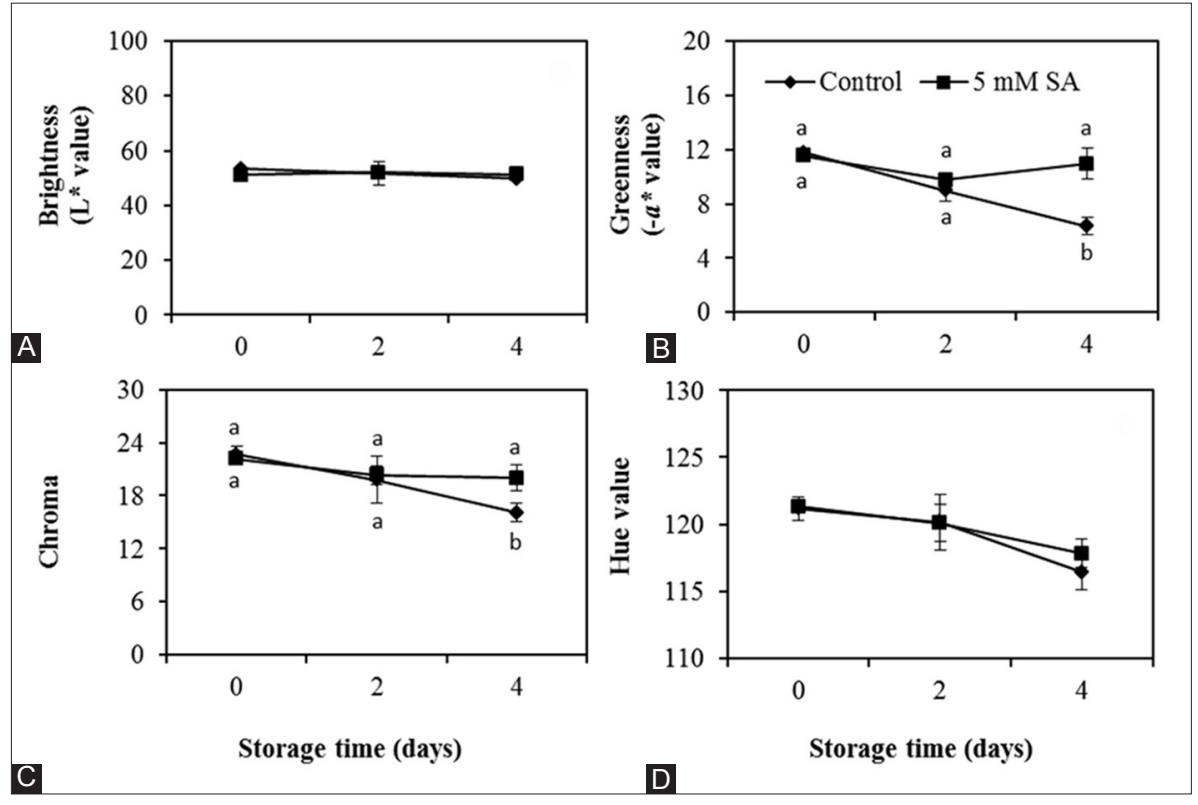

Fig 3. Superficial colour, brightness (A), greenness (B), chroma (C) and hue value (D) of lemon basil preharvest-treated with 0 and $5 \mathrm{mM}$ SA during storage at $7 \pm 1^{\circ} \mathrm{C}$ for 4 days. Data represent the mean of four replications \pm S.D.

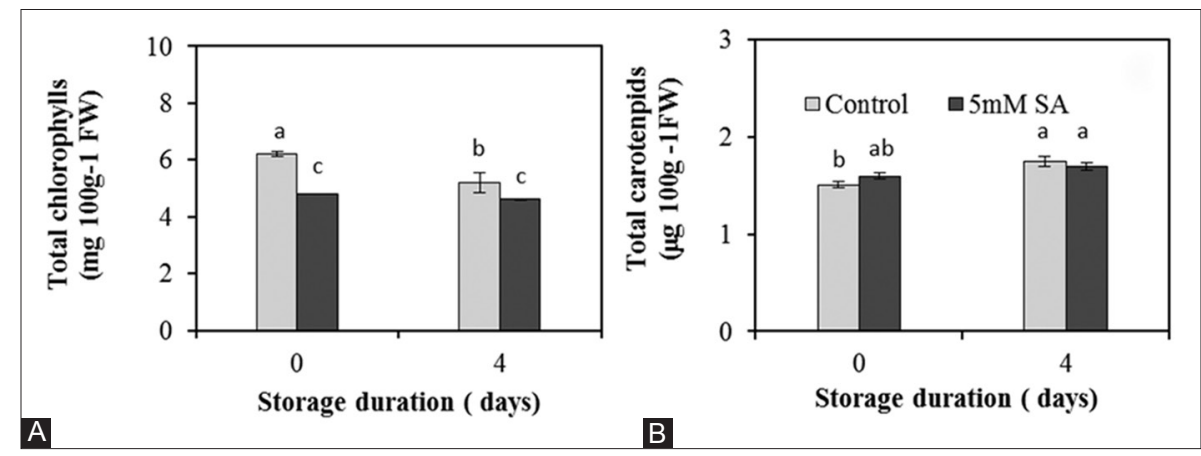

Fig 4. Pigments content, total chlorophylls $(A)$ and total carotenoids $(B)$, of lemon basil preharvest-treated with 0 and $5 \mathrm{mM}$ SA during storage at $7 \pm 1{ }^{\circ} \mathrm{C}$ for 4 days. Data represent the mean of four replications \pm S.D. 
Total phenols, total flavonoids, FRAP value and $\mathrm{H}_{2} \mathrm{O}_{2}$ scavenging activity

Antioxidant activities involving FRAP value and $\mathrm{H}_{2} \mathrm{O}_{2}$ scavenging activity, TP and TF content which known as the biologically active compounds benefiting human health were commonly investigated in fresh commodities. After preharvest SA spray for $24 \mathrm{~h}, \mathrm{TP}, \mathrm{TF}$ and FRAP value of SA-treated lemon basil were significantly higher than those of the control $(P<0.05)$; whereas, $\mathrm{H}_{2} \mathrm{O}_{2}$ scavenging activity of both treatments was similar (Fig. 5). TP, TF and FRAP value of both SA-treated and untreated lemon basil decreased over storage. No significant difference in TP and TF content were found at the end of storage but FRAP value of SA-treated lemon basil was higher than that of the control. We also found that $\mathrm{H}_{2} \mathrm{O}_{2}$ scavenging activity of SA-treated lemon basil was maintained whilst that of the control significantly decreased. Recent studies on fruit and vegetables have shown that their antioxidant efficiency may be contributed to a range of bioactive compounds such as phenolics and flavonoids content (Rapisarda et al.,1999; Wei et al., 2011) and antioxidant enzymes (Supapvanich et al., 2012). SA actively induced or maintained FRAP and free radical scavenging activity as reported for asparagus (Wei et al., 2011). In the similar vien, FRAP value, TP and TF content in SA-treated rambutan fruit (Supapvanich 2015) and peach fruit (Razavi et al.,2014) were higher than those of the untreated fruits. These confirm that SA induces biologically active compound in fresh produce which due to the stimulation of defense mechanism as described by Supapvanich and Promyou (2013). The higher bioactive compound of SA-treated lemon basil after preharvest spray $24 \mathrm{~h}$ might induce the tolerance to chilling temperature during storage.

\section{CAT, G-POD, A-POD activities}

CAT, G-POD and A-POD are known as the antioxidant enzymes playing important roles in removing $\mathrm{H}_{2} \mathrm{O}_{2}$ which recognised as a ROS (Elwan and El-Hamahmy, 2009). As shown in Table 1, CAT activity of the lemon basil was induced after SA spray for $24 \mathrm{~h}$; whereas, both G-POD and A-POD activities of SA-treated lemon basil did not different from the control. During storage, all antioxidant enzyme activities of the control decreased considerably whilst those of SA-treated lemon basil remained constant. The stimulation of G-POD and A-POD activities by SA plays a key roles in preventing the increase of $\mathrm{H}_{2} \mathrm{O}_{2}$ in plant tissues (Kang et al., 2003; Shi et al., 2006). The high level of these antioxidant enzyme activities in the SA-treated lemon basil on day 4 were positively related to the level of $\mathrm{H}_{2} \mathrm{O}_{2}$ scavenging activity as shown in Fig. 5D. These were also concomitant with the CI suppression and the maintained membrane integrity as shown in Fig 1 and 2.

\section{CONCLUSION}

In conclusion, preharvest $\mathrm{SA}$ treatment was effectively able to delay CI symptom of the lemon basil during refrigerated storage at $7^{\circ} \mathrm{C}$. Preharvest $\mathrm{SA}$ treatment at $5 \mathrm{mM}$ showed the best results suppressing $\mathrm{CI}$ and maintaining superficial colour and total chlorophylls content. Regarding to CI alleviation, preharvest $\mathrm{SA}$ treatment retarded the increase in EL and MDA content. The higher bioactive compounds of SA-treated lemon basil played an important role maintaining postharvest quality and alleviating CI symptom during refrigerated storage.

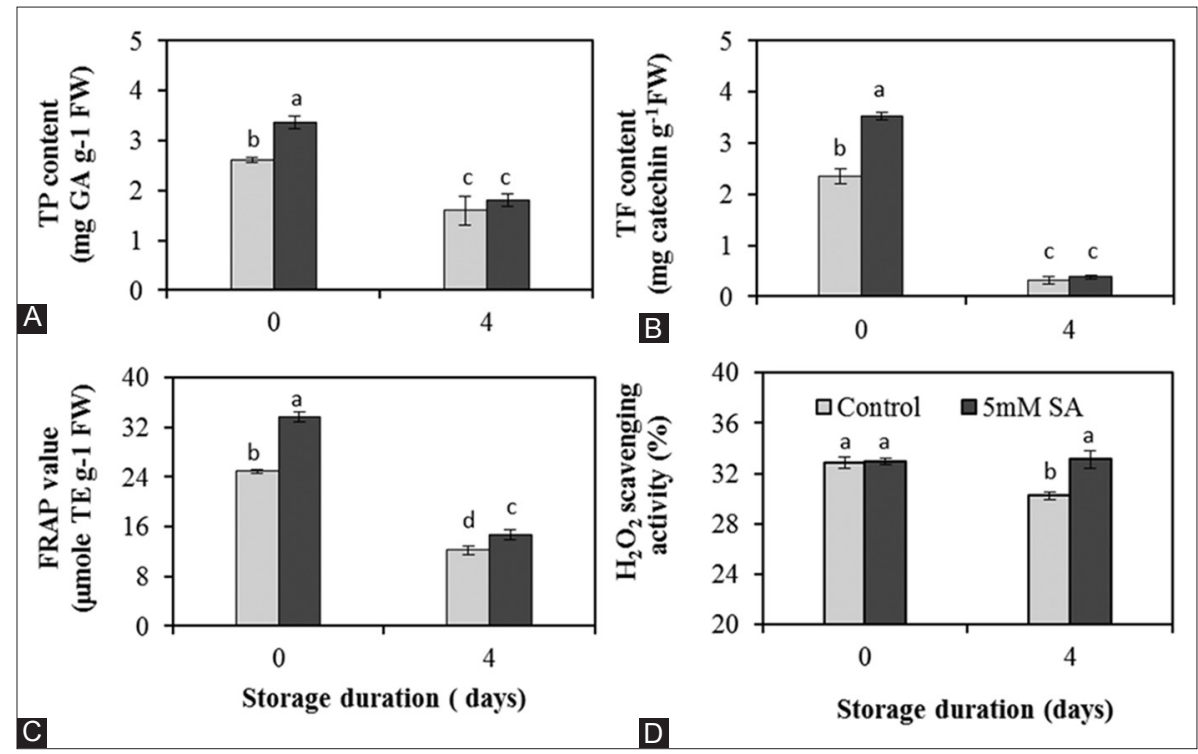

Fig 5. Total phenolics (TP) content (A), total flavonoids (TF) content (B), FRAP value (C) and H2O2 scavenging activity (D) of lemon basil preharvest-treated with 0 and $5 \mathrm{mM} \mathrm{SA}$ during storage at $7 \pm 1^{\circ} \mathrm{C}$ for 4 days. Data represent the mean of four replications $\pm S$.D. 


\section{ACKNOWLEDGEMENTS}

We would like to thank Faculty of Industrial Education for facilities and financial support in this research project.

\section{Author contributions}

S. Supapvanich was the project director who planned the overall experiments, interpreted and analyzed data and wrote this article. R. Phonpakdee supervised basil cultivation and reviewed the article. P. Wongsuwan collected raw data and measured certain physicochemical factors.

\section{REFERENCES}

Andrade Cuvi, M. J., A. R. Vincente, A. Concellón, and A. R. Chaves. 2011. Changes in red pepper antioxidants as affected by UV-C treatments and storage at chilling temperature. LWT - Food Sci. Technol. 44: 1666-1671.

Awad, A. M., A. D. Al-Qurashi and M. I. Elsayed. 2013. Effect of prestorage salicylic acid and oxalic dipping on chilling injury and quality of 'Taify' pomegranates during cold storage. J. Food, Agric. Environ. 11: 117-122.

Barbalar, M., M. Asghari, A. Talaei and A. Khosroshahi. 2007. Effect of pre- and postharvest salicylic acid treatment on ethylene production, fungal decay and overall quality of Selva strawberry fruit. Food Chem. 105: 449-453.

Benzie, I. F. F. and J. J. Strain. 1996. The ferric reducing ability of plasma (FRAP) as a measure of "Antioxidant power": the FRAP assay. Analyt. Biochem. 239: 70-76.

Elwan, M. W. M. and M. A. M. El-Hamahmy. 2009. Improved productivity and quality associated with salicylic acid application in green house pepper. Scientia Hort. 122: 521-526.

Gülçin, I., M. Elmastaş and H. Y. Aboul-Enein. 2007. Determination of antioxidant and radical scavenging activity of basil (Ocimum basilicum L. Family Lamiaceae) assayed by different methodologies. Phytotherapy Res. 21: 354-361.

Heath, R. L. and L. Packer. 1968. Photoperoxidationin isolated chloroplasts: II. Role of electron transfer. Arch. Biochem. Biophys. 125: 850-857.

Jia, Z., M. Tang and J. Wu. 1999. The determination of flavonoid contents in mulberry and their scavenging effects on superoxide radical. Food Chem. 64: 555-559.

Kang, G. Z., C. H. Wang, G. C. Sun and Z. X. Wang. 2003. Salicylic acid changes activities of $\mathrm{H}_{2} \mathrm{O}_{2}$-metabolizing enzymes and increases in chilling tolerance of banana seedlings. Environ. Exp. Bot. 50: 9-15.

Kar, M. and D. Mishra. 1976. Catalase, peroxidase and polyphenoloxidase activities during rice leaf senescence. Plant Physiol. 57: 315-319.

Kazemi, M., M. Aran and S. Zamani. 2011. Effects of calcium chloride and salicylic acid treatment on quality characteristics of kiwifruit (Actinidia deliciosa cv. Hayward) during storage. Amer. J. Plant Physiol. 6: 183-189.

Kirk, J. T. O. 1968. Studies on the dependence of chlorophyll synthesis on protein synthesis in Euglena gracilis, together with a nomogram for determination of chlorophyll concentration. Planta 78: 200-207.
Li, N., L. P. Barbara, D. R. Liu and K. M. Autar. 1992. Accumulation of wound-inducible ACC synthase transcript in tomato fruit is inhibited by salicylic acid and polyamines. Plant Molec. Biol. 18: 477-487.

Lukaszewska, A. and D. Kobylińksi. 2009. Salicylic acid delays senescence of detached leaves of Hippeastrum x chmielii. Annual Warsaw Univ. Life Sci. - SGGW, Hort. Landscape Architec. 30: 23-29.

Luo, Z., C. Chen and J. Xie. 2011. Effect of salicylic acid treatment on alleviating postharvest chilling injury of 'Qingnai' plum fruit. Postharvest Biol. Technol. 62: 115-120.

McCollum, T. G. and R. E. McDonald. 1991. Electrolyte leakage, respiration, and ethylene production as indices of chilling injury in grapefruit. HortSci. 26: 1191-1192.

Pongprasert, N. and V.Srilaong. 2007. Change of oil gland during chilling injury development of sweet basil leaves. Agric. Sci. J. 38 (6) (Suppl.): 185-188.

Promyou, S., S. Supapvanich, B. Boodkord and M. Thanapiradeekajorn. 2012. Alleviation of chilling injury in jujube fruit (Ziziphusjujuba Mill) by dipping in $35^{\circ} \mathrm{C}$ water. Kasetsart J. Nat. Sci. 46: 107 - 119.

Radwan, D. E. M., G. Lu, K. A. Fayez and S. Y. Mahmoud. 2008. Protective action of salicylic acid against bean yellow mosaic virus infection in Vicia faba leaves. J. Plant Physiol. 165: 845-857.

Rapisarda, P., A. Tomaino, C. R. Lo, F. Bonina, P. A. De and A. Saija. 1999. Antioxidant effectiveness as influenced by phenolic content of fresh orange juices. J. Agric. Food Chem.47: 4718-4723.

Razavi, F., J. Hajilous, G. Ehgan, R. N. Hassani and H. M. Turchi. 2014. Enhancement of postharvest quality of peach fruit by salicylic acid treatment. Inter. J. Biosci. 4: 177-184.

Shi, Q., Z. Bao, Z. Zhu, Q.Ying and Q. Qian. 2006. Effects of different treatments of salicylic acid on heat tolerance, chlorophyll fluorescence, and antioxidant enzyme activity in seeding of Cucumis sativa L. Plant Growth Reg. 48: 127-135.

Slinkard, K. and V. L. Singleton. 1977. Total phenol analysis: automation and comparison with manual methods. Amer. J. Enol. Viti. 28: 49-55.

Supapvanich, S., R. Arkajak and K. Yalai. 2012. Maintenance of postharvest quality and bioactive compounds of fresh-cut leaf bush (Saurapus androgynous L. Merr.) through hot $\mathrm{CaCl}_{2}$ dips. Inter. J. Food Sci. Technol. 47: 2662-2670.

Supapvanich, S. and S. Promyou. 2013. Effeciency of salicylic acid application on postharvest perishable crops. In: Hayat, S., \& Alyemei, A. A. M. N. (Eds), Salicylic acid: Plant growth and development, Springer, New York USA. Pp. 339-355.

Supapvanich, S. 2015. Effects of salicylic acid incorporated with lukewarm water dips on the quality and bioactive compounds of rambutan fruit (Nephelium lappaceum L.). CMU. J. Nat. Sci. 14(1): 23-27.

Wei, Y., Z. Liu, Y. Su, D. Liu and X. Ye. 2011. Effect of salicylic acid treatment on postharvest quality, antioxidant activities, and free polyamines of asparagus. J. Food Sci. 76: 126-132.

Wongsheree, T., S. Ketsa and W. G. van Doorn. 2009. The relationship between chilling injury and membrane damage in lemon basil (Ocimum $x$ citriodourum) leaves. Postharvest Biol. Technol. 51: 91-96.

Zhang, X. Y. 2000. Principle of chemical analysis, China Science Press, Beijing, Pp. 275-276. 